\title{
Seismic Behaviour of Point Fixed Glass Façade Systems: State of the Art Review
}

\author{
Eliana Inca ${ }^{1}$, Sandra Jordão ${ }^{2}$, Carlos Rebelo $^{3}$, Constança Rigueiro $^{4}$, Rui Simões ${ }^{5}$ \\ ${ }^{1}$ E. I. is a PhD Candidate of the ISISE Dep. Eng. Civil, University of Coimbra, Coimbra, Portugal. \\ ${ }^{2}$ S. J. is an Assistant Professor of the ISISE Dep. Eng. Civil, University of Coimbra, Coimbra, \\ Portugal \\ ${ }^{3}$ Ca. R. is an Associated Professor of the ISISE Dep. Eng. Civil, University of Coimbra, Coimbra, \\ Portugal \\ ${ }^{4}$ Co. R. is an Adjunct Professor of the Dep. Eng. Civil, Instituto Politécnico Castelo Branco, \\ Castelo Branco, Portugal \\ ${ }^{5}$ R. S. is an Assistant Professor of the ISISE Dep. Eng. Civil, University of Coimbra, Coimbra, \\ Portugal
}

\section{ARTICLE INFO}

\section{Keywords:}

facade systems, point

fixed glass systems, structural glass, seismic action

\begin{abstract}
flat glass has been used for many centuries in wall openings and windows. It allows light in and broadens the visual horizon, while protecting from the environmental elements. It also features a good potential for energy savings during the lifetime of the building. The technological developments it benefited from, in the last decades, transformed common plate glass into a stronger material, with safer and more predictable failure and some degree of post breakage capacity; even pseudo-ductility. For this reason, at present day, glass is a structural material with established credits. This allows for new buildings with dematerialized contours: the glass skin buildings; which are taking over the set in modern cities. There are several types of glass façade buildings, depending on the system used to fix the glass to the main structure. Point Fixed Glass Façade Systems (PFGFS) feature an advantage in terms of architectural expression allowing for greater transparency, since no mullions and frames are required for additional support, only discrete point fixing. The design codes for structural glass are still under development, and one of the aspect that needs further attention is the behaviour of PFGFS when subjected to seismic action. This aspect is of the essence in the sense that forensic analysis to past earthquake events showed that important damage has been observed to GFS due to the in-plane racking actions. This may have severe costs in terms of human losses and in terms of economic costs (repair and downtime). The present paper addresses this theme by presenting an overview of its key aspects, review of past research, both analytical and experiment for PFGFS under seismic loads, design code provisions for different countries as well as recommendations for prediction of racking capacity of Point Fixed Glass Façade Systems. The work presented in this paper is established in the framework of the ongoing research project: GF Seismic (FCT POCI-01-0145-FEDER-032539).
\end{abstract}

$\square$ Corresponding Author E-Mail Address: e.inca.cabrera@uc.pt 


\section{Introduction}

Glass is a sustainable material (basically made from $75 \%$ molten sand and $25 \%$ chalk soda and can be $100 \%$ recycled [1], it is transparent and slender, and can create the feeling of real contact with the exterior. Is important to notice that façade systems play an important role in buildings in order to provide entrance of sun light, air protection, most importantly adequate indoor environments by controlling comfort and adequate use of energy (both for heating and cooling). Different materials can be used for façade systems, the selection will depend on the architectural design of the building, two types of façades can be distinguished [2]: i) Opaque façades, constructed with layers of solid materials such as masonry, stone, precast concrete panels, metal (aluminium, stainless steel). ii) Glazed Facades, such as curtain walls or storefront facades, consisting in translucent glazing material and metal framing as secondary components.

Current tendency for building construction aims to create lighter, bigger and more spacious facilities, therefore frameless glass façade systems have gained popularity over the past thirty years, due to their ability to allow high transparency on the building's façade while using less elements for the support of the glass panels. The current use of bolted structural glass façades started with the plate suspended assemblies of the 1960's and 70's [3], with the introduction of Pilkington's Planar system in 1981 followed by RFR's La Villete ball-joint systems to nowadays point fixing techniques. Modern frameless glass façade systems include bolted spider arms connections, providing a point support on the glass panels usually on the corners of each glass panel, according to its size intermediate points may be required. Structural supports for these systems may vary from truss, cable and steel support systems [4]. In general, in a Glass Façade System (GFS), four basic components may be identified: glazing panels, bolted fixings, glazing support attachments and the main support structure.

Damage To Glass Façade Systems In Past Earthquakes

Non-structural damage has been constantly reported in past earthquakes [5], investment on nonstructural components in construction (including contents) for a typical office are $82 \%$ and for hospitals up to $92 \%$ of total building costs [6], pointing out the great investment there is in nonstructural components and contents rather than structural components and framing. After the San Fernando earthquake in 1971 (California), where several buildings were reported with glass damage [7], it became clear that non-structural components can be very vulnerable to strong shaking, damage to non-structural components not only can be very costly but also can pose real threat to life safety, therefore reducing damage to those elements has been an important engineering task for the past decades.

From the 1985 Mexico City strong earthquake some lessons were learned on glass damage, window glass falling was the second most serious non-structural damage well documented [8]. On the latest strong earthquake on 19th September 2017 Puebla, Mexico, damage was reported on medium high buildings (8-12 stories) and mostly due to structural irregularities, important nonstructural damage was observed on in-fill walls (masonry facades of buildings were severely damaged) and glass window falling according [9].

An important correlation between the inter-storey drift and the glass damage was reported on several post-earthquake damage assessments [10]. Flexible glass façade systems enclosed by metal curtain walls and mullions presented less damage in past seismic events [11], mainly due to the high deformability of silicon allowing for a better accommodation of drift demand during ground shaking. Further, it is reported that glass damage consistently increases with larger window areas and irregular plan configurations [12]. Therefore, due to the significant increase of glass usage in 
buildings, an increasing interest rise about controlling their possible damage. An example of curtain glazing falling out is shown in figure 1 .

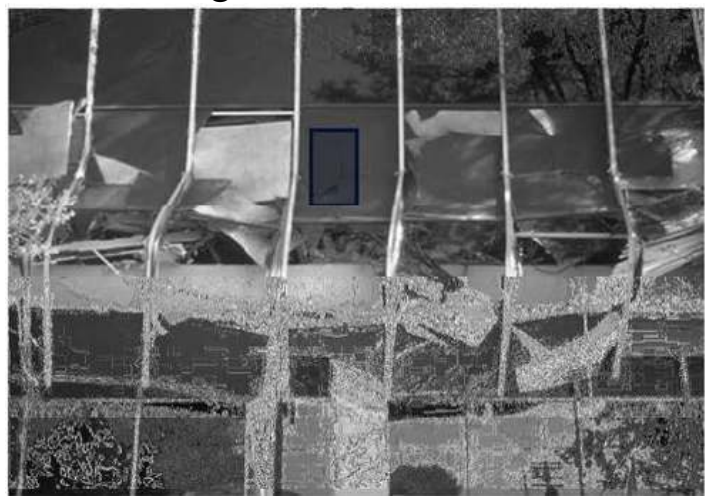

Fig. 1. Kaiser Permanetate Building, Granada Hills, California, cladding offset [6].

A damage extent report of the Christchurch earthquake in 2011 (New Zeeland,) showed that heavy damage was observed in spider glazing [10], as can be seen in figure 2, this behaviour was originated around the "spider" that holds each glass pane, likely a result of the "spider" creating stress concentrations in these regions due to the restraint of the connection to the structure. In table 1 is presented a resume of percentage of glass damage per seismic event for some of the significant earthquake events of the past 50 years, in figure 3 a chart with the data from table 1 is shown.
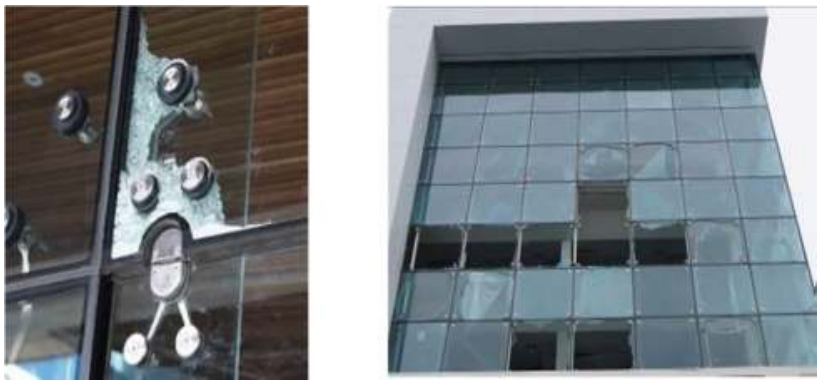

Fig. 2. Examples of damage to spider glazing systems on buildings [10]. 
TABLE I: DESCRIPTION OF PERCENTAGE OF DAMAGED GLASS FAÇADES ON PAST EARTHQUAKES.

\begin{tabular}{|c|c|c|c|}
\hline $\begin{array}{l}\text { SEISMIC } \\
\text { EVENT }\end{array}$ & DATE & DAMAGE ON & DATA \\
\hline $\begin{array}{lr}\text { San } & \text { Fernando } \\
\text { (SF), } & \text { California, } \\
\text { USA } & \\
\end{array}$ & $\begin{array}{l}9-F e b- \\
1971\end{array}$ & $\begin{array}{l}30 \% \text { of building's façades sustained } \\
\text { broken glass }\end{array}$ & $\begin{array}{l}50 \text { high rise buildings in } \\
\text { locations away from the } \\
\text { epicenter }[49 ; 50] .\end{array}$ \\
\hline $\begin{array}{l}\text { Guerrero- } \\
\text { Michoacan (GM), } \\
\text { Mexico }\end{array}$ & $\begin{array}{l}\text { 19-Sep- } \\
1985\end{array}$ & $\begin{array}{l}50 \% \text { of buildings with structural } \\
\text { damage presented glass damage. } \\
25 \% \text { of buildings presented serious } \\
\text { damage and glass falling. }\end{array}$ & $\begin{array}{l}263 \text { multi-story office } \\
\text { buildings }[8 ; 49]\end{array}$ \\
\hline \multirow[t]{2}{*}{$\begin{array}{l}\text { Northridge (No), } \\
\text { California, USA }\end{array}$} & \multirow[t]{2}{*}{$\begin{array}{l}17-E n- \\
1994\end{array}$} & $\begin{array}{l}25 \% \text { of the storefront windows } \\
\text { presented damage }\end{array}$ & \multirow{2}{*}{$\begin{array}{l}\text { Over } 14 \text { buildings with } \\
\text { limited non-structural } \\
\text { damage and no structural } \\
\text { damage reported in } \\
\text { downtown Bunbank } \\
\text { [49]. } \\
\text { High rise curtain walls } \\
\text { systems. }\end{array}$} \\
\hline & & $\begin{array}{l}\text { CW systems in general performed } \\
\text { well, damage was more frequent for } \\
\text { low-rise storefront windows. }\end{array}$ & \\
\hline \multirow[t]{2}{*}{ Kobe (Ko), Japan } & \multirow[t]{2}{*}{ 17-Jan-95 } & $\begin{array}{l}\text { General glass fracture and } \\
\text { deformation on glazing frames, } \\
\text { differences were observed in façade } \\
\text { orientation, southerly oriented } \\
\text { glazing panels were damage above } \\
70 \% \text { in comparison to northerly } \\
\text { façades with less than } 15 \% \text { damage. }\end{array}$ & \multirow[t]{2}{*}{$\begin{array}{l}\text { Several buildings were } \\
\text { asses, low (up to } 60 \mathrm{~m} \\
\text { height) to height } \\
\text { buildings (above } 60 \mathrm{~m} \\
\text { height) [49]. }\end{array}$} \\
\hline & & $\begin{array}{l}\text { Tall buildings didn't showed } \\
\text { representative structural damage nor } \\
\text { major glazing damage. }\end{array}$ & \\
\hline Bam (Ba), Iran & $\begin{array}{l}\text { 26-Dec- } \\
2003\end{array}$ & $\begin{array}{l}70 \% \text { buildings of the area were } \\
\text { destroyed and buildings with no } \\
\text { significant structural damage } \\
\text { presented important non-structural } \\
\text { damage (glass fallout). }\end{array}$ & $\begin{array}{l}\text { Field investigation in } \\
\text { Bam epicenter town of } \\
\text { several medium to height } \\
\text { buildings [13]. }\end{array}$ \\
\hline $\begin{array}{l}\text { Christchurch }(\mathrm{Ch}) \text {, } \\
\text { New Zeland }\end{array}$ & $\begin{array}{l}\text { 22-Feb- } \\
2011\end{array}$ & $\begin{array}{l}\text { The glass damage was recorded for all } \\
\text { lightweight cladding that contained } \\
\text { glass. Nearly half of all glazed } \\
\text { lightweight claddings had glazing } \\
\text { damage and } 39 \% \text { presented a falling } \\
\text { hazard. Only } 60 \% \text { of infill systems } \\
\text { were deemed either operational or } \\
\text { immediate occupancy. } 17 \% \text { were }\end{array}$ & $\begin{array}{l}371 \text { façade systems on } \\
271 \text { buildings were } \\
\text { surveyed }[10] .\end{array}$ \\
\hline
\end{tabular}


deemed high hazard, the highest of the facade groups.

\begin{tabular}{|c|c|c|c|}
\hline Central (Ce), Italy & $\begin{array}{l}\text { 30-Ago- } \\
2016\end{array}$ & $\begin{array}{l}\text { Overall good performance of glazing } \\
\text { systems attributed to the quality of the } \\
\text { interface between the glass panels and } \\
\text { the supporting frames (silicon). }\end{array}$ & $\begin{array}{l}\text { From } 300 \text { inspected } \\
\text { buildings with different } \\
\text { structural systems } \\
\text { (schools, hospitals, } \\
\text { public and residential } \\
\text { buildings) [52]. }\end{array}$ \\
\hline $\begin{array}{l}\text { Kaikōura } \\
\text { Japan }\end{array}$ & $\begin{array}{l}\text { 13-Nov- } \\
2016\end{array}$ & $\begin{array}{l}\text { Entire temperate glass panels } \\
\text { shattering due to stress } \\
\text { concentrations, this behavior was } \\
\text { attributed to the incapability of } \\
\text { traditional systems to accommodate } \\
\text { structural deformations (the amount } \\
\text { of the deformation the spider glazing } \\
\text { system can accommodate is around } \\
1 \% \text { drift ratio) with no redundancy } \\
\text { like framed systems. }\end{array}$ & $\begin{array}{l}\text { Several multi-story } \\
\text { buildings of modern } \\
\text { construction (built in the } \\
\text { 1980s or recently) in } \\
\text { Wellington observed in } \\
\text { the immediate aftermath } \\
\text { of the Kaikoura } \\
\text { earthquake [14]. }\end{array}$ \\
\hline $\begin{array}{l}\text { Mexico City } \\
(\mathrm{MC}), \text { Mexico }\end{array}$ & $\begin{array}{l}\text { 19-Sep- } \\
2017\end{array}$ & $\begin{array}{l}40 \% \text { of the buildings suffered } \\
\text { substantial damage on façades and } \\
\text { structural components. }\end{array}$ & $\begin{array}{l}25 \text { buildings with } \\
\text { different features and full } \\
\text { range of damage, from } 8 \\
\text { to } 12 \text { th stores [9]. }\end{array}$ \\
\hline
\end{tabular}

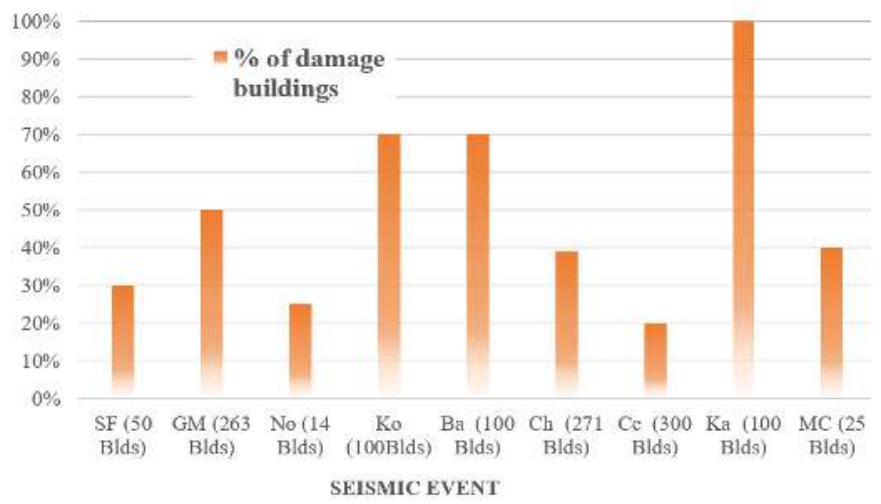

Fig. 3. Percentage of damage per major seismic event listed on table 1. 
Structural Façade Configuration For Point Fixed Glass Façade Systems

Different point fixed glass façade systems (PFGFS) were developed due to architectural requirements, over time, industry evolved according to market necessities, even though glass façade systems are not standardized, four basic components can be identified for bolted glazing systems and are explained below: glazing panels, bolted fixings, glazing support attachments and main support structure.

Glazing Panels

Usually toughened glass and laminated glass are the most common types of glass panels used for façades. Toughened glass induces a favourable tension field all over the surface of the glass panels due to a process of heating the panels at high temperatures $\left(600^{\circ} \mathrm{c}-650^{\circ} \mathrm{C}\right)$ followed by a rapidly cooling process, allowing balanced stress condition across the thickness of the glass panel, one important property of this type of glass panels is the capacity of fragmenting into small particles after fracture.

Laminated glass, on the other hand, is produced by a process of bonding two or more layers of glass with an intermediate interlayer. The most popular interlayer is PVB (polyvinyl butyral), other type of interlayers are: Ethylene Vinyl Acetate EVA or SentryGlass (SG). Commonly known as safety glass, when subjected to sufficient impact to break the glass, fragments typically remain intact, firmly adhered to the PVB interlayer [15]. Depending on factors like shape, size of glass, edge treatment, quality of holes, etc. Resistance of the glass panel will vary, for point fix glass, stresses near the holes and glass thickness will determine the resistance of the panels and final design will take into account panel deflection.

\section{Bolted Fixings}

Bolted fixings provide point support to the glass panels and transfer the glass self-weight and lateral loads to the structural support. The bolted fixings are usually located towards the corners of the glass panels and additionally at intermediate points on long edges. Several types of bolts exist: enhanced countersunk fixings (allow to transfer out of plane and in plane loads directly through to the bolt and glass interface), articulated bolts fixings (allow for accommodate rotation of the fixing to glaze support), different type of spider arms and bolt fittings are shown in figure 4 . All hardware is made of high quality mirror polished stainless steel (graded 304, 316, 316LM), ensuring best possible protection against oxidation and corrosion. Principal elements of a spider arms fixing are shown in figure 5.

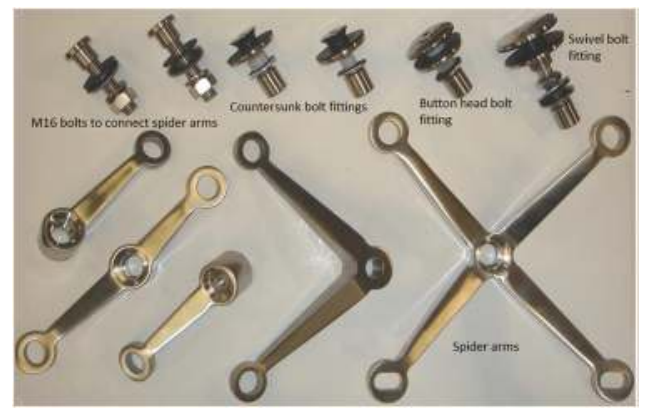

Fig. 4. Spider arms and bolt fittings for the PFGFS connections [16]. 


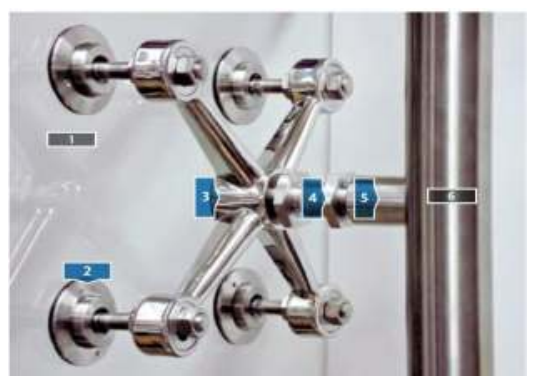

1. Glass panel

2. Articulated bolts rotules (patchfittings)

3. Spider arm

4. Exterior bolt

5. Support rod

6. Support structure

Fig. 5. Glass façade spider arms components [17].

There is no direct contact between glass panels and steel bolts, an intermediate polymer material with smaller elastic modulus is used to help with the uniform distribution of tension around the holes. Bolts can be placed with the head inside or outside the glass panels, also double glazing systems can be used introducing a special bolt fixing allowing this feature (in figure 6 are displayed different types of bolts). A point fixing embedded in the glass panel is also possible as well as silicon fixing of the bolts to the glass panels, although those systems may be of limited use due to its durability in a long term behaviour [17].

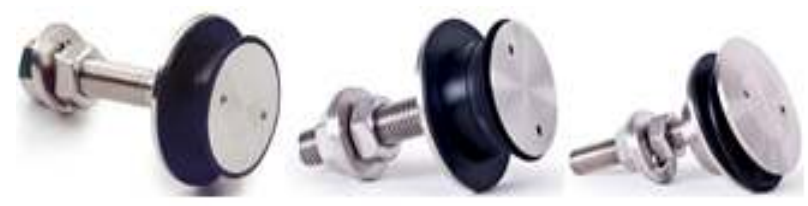

Fig. 6. Different type of bolts for interior point fixing (from [18]).

\section{Glazing Support Attachments}

Glazing support attachments provide mechanical support and allow the transfer of loads to the main support system. Many types exist on the market, some of them are: Spider supports, angle brackets, pin brackets and clamping devices, in general these attachments are defined by an architectural/aesthetics assessment on the façades.

Support Structure

The main job of the support structure is to transfer loads from the glazing support attachments to the building structure itself, as well as for the glazing support attachments, support structures may be different according to the architectural requirements, but two of the most common systems are steelwork structures (trusses and fins) and cable systems (rod or wires working under tension loads), figure 7 shows examples of those systems.

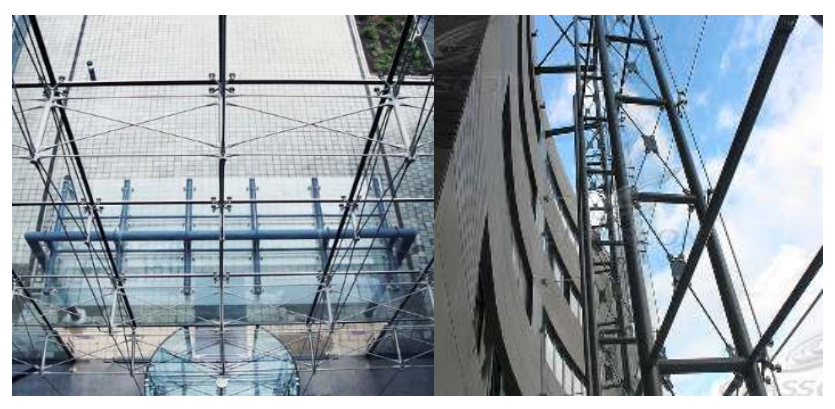


Fig. 7. Examples of façade support structures from GLASSCON Projects (from web site [18]). Analytical and Experimental Studies for PFGFS

Experimental and analytical studies have been performed over the past 30 years for seismic performance of framed glass façade systems, focusing on their behaviour after mayor earthquakes ([12]; [20]; [21]; [22]). One of the most significant experimental work on this topic developed at the Building Envelope Research Laboratory of the University of Missouri-Rolla (UMR), investigating the serviceability and fallout resistance of popular curtain wall systems used on midrise buildings under simulated earthquake [23]. Figure 8 shows the test set-up used for the testing program at UMR.

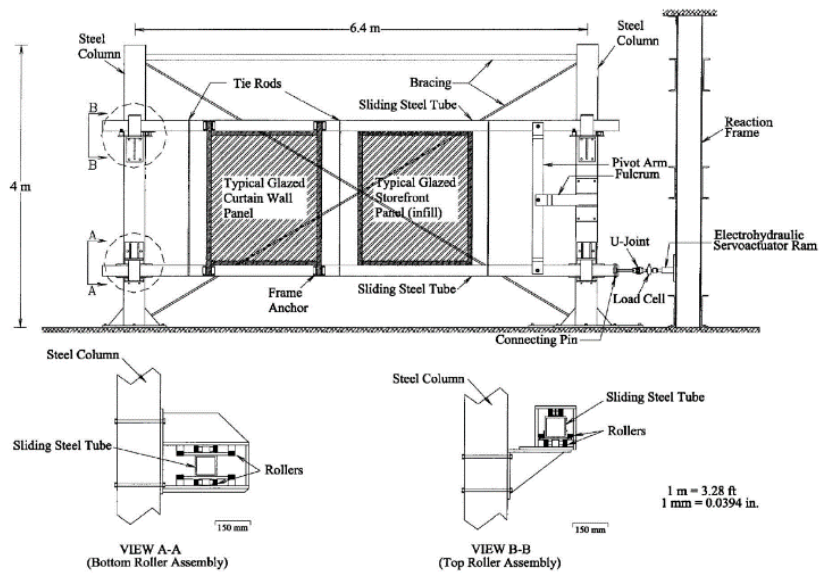

Fig. 8. Dynamic Racking Test facility at the Building Envelope Research Laboratory Department of architectural Engineering, The Pennsylvania State University [23].

The so called "crescendo tests" were performed by means of hydraulic controlled actuators increasing lateral displacement to glazed systems, figure 9 shows the sinusoidal progressively increasing racking amplitudes. Those experimental studies lead to a number of recommended revisions, namely: "NEHRP Recommended Provisions for the Seismic Regulations for New Buildings and Other Structures (FEMA 450)" which were published in the 2000 NEHRP Provisions FEMA 451 [45]. The experimental work layout allowed to develop industry-accepted test protocols published by the American Architectural Manufacturers Association (AAMA) as: "Recommended dynamic test method for determining the seismic drift causing glass fallout from a wall system" published on AAMA 501.6 in 2001 ([24]; [25]; [26]).

Several tests were conducted based on AAMA 501.6 test set-ups for framed glass façades, e.g. the work developed by [27]-[28] on full-scale curtain walls with IGU configurations, in order to determine service and ultimate limit drift behaviour and glass fitted with anchored pet film among others [29].

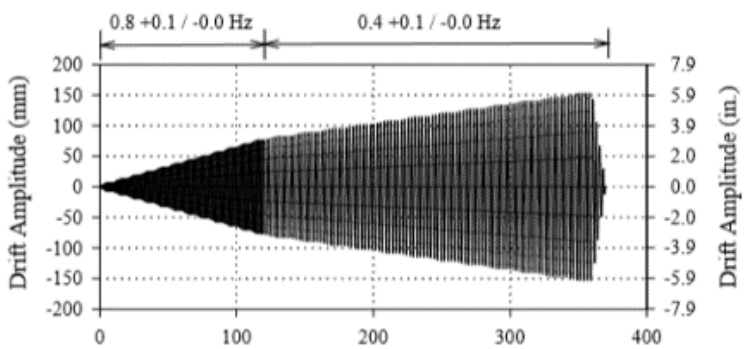


a) for full time load

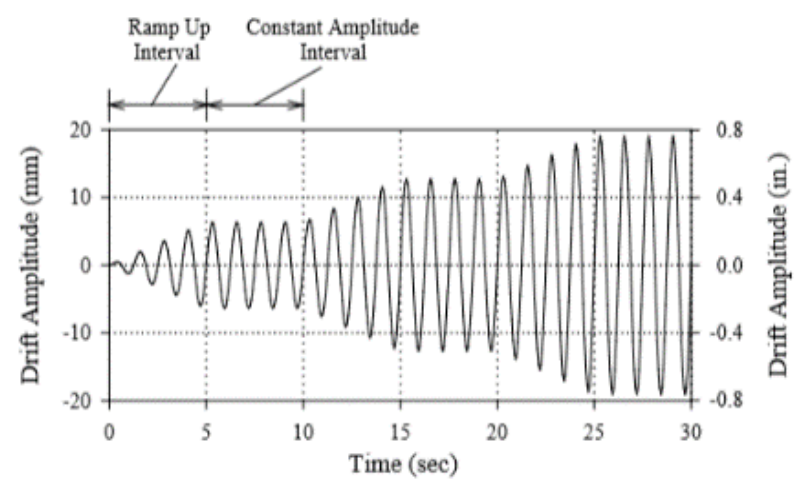

b) for the first 30 seconds of time.

Fig. 9. Crescendo load path for dynamic test.

For Point Fixed Glass Facade Systems (PFGFS), a limited number of recent experimental tests and analytical studies have been performed. Experimental work and Finite Element (FE) models were developed to study parameters such as clearance between bolt and holes, variation in hole diameter and distance between hole and glass panel edge. It has been reported that for in-plane loads on glass panels, increasing the clearance between bolt to glass hole and the distance between hole and panel edge, enhanced the stress development on the glass panels [30].

In order to improve the behaviour of PFGFS in areas of high seismicity, the seismic performance of specially design spider arm systems connecting the glass to structural support frames was assessed [31]-[32], including large horizontally slotted holes allowing isolated horizontal translation (figure 10), for that purpose, special low modulus silicon sealant was used to allow rigid body translation during the racking actions. The sizes of the slotted holes need to be calculated according to the glass façade drift demands from the building. During the experimental test [30], the façade frame was subjected to in-plane displacement in incremental magnitudes of three cycles of elastic drift condition $(0.4 \%)$, one cycle of inelastic drift condition $(2.5 \%)$ and a third drift capacity of (2.9\%). The system behaved very well, accomplishing all code criteria with glass panels remaining intact, only when the frame was racked beyond the design range of the spider slots the glass panels showed noticeable rotation but no glass nor bolt failure were observed.

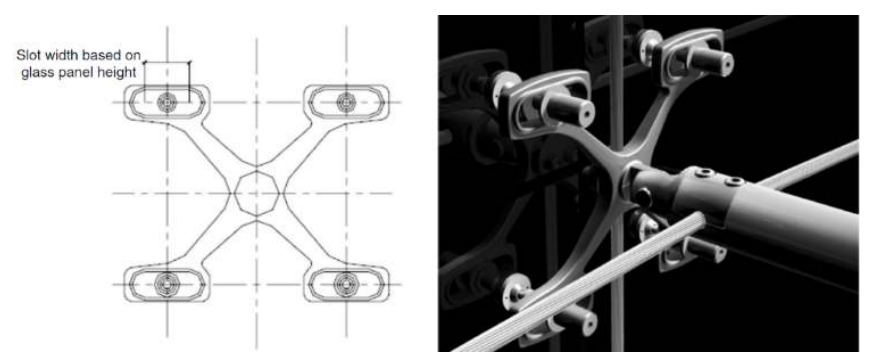

Fig. 10. Spider arms with horizontally slotted holes [31].

A standard testing protocol was developed [33] and use to undertake racking test on typical PFGFS for low moderate seismic regions such as Australia. The test results allowed to calibrate finite element models that were extended to other PFGFS systems and geometric configurations. The aim was to assess the in-plane racking performance of PFGFS in terms of its lateral drift capacity, for this purpose two full-scaled laboratory tests were developed: a) with X type spider arms and 
countersunk bolt fittings for laminated glass panels joined with silicon weather sealant, b) K-type spider arms and button head bolt fittings. Both tests were subjected to $100 \mathrm{kN}$ in-plane lateral load and more than $150 \mathrm{~mm}$ in plane displacement, figure 11 shows the test layout.

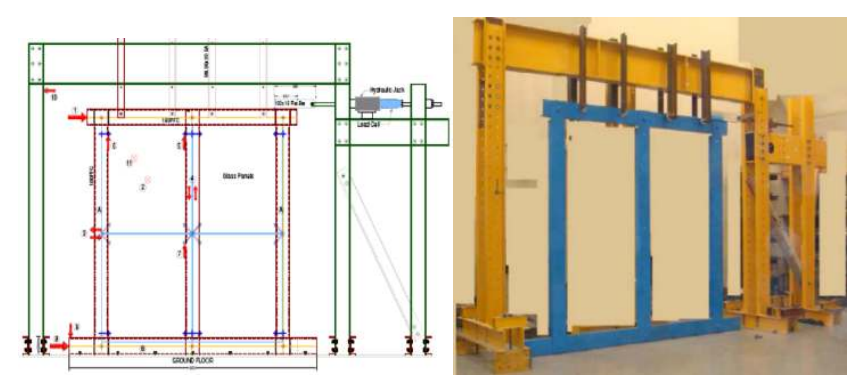

Fig. 11. Structural support frame for reaction frame and location of LVDTs and hydraulic jack [33].

Two tests were completed, PFGFS with pinned X-type (test \#1) and fixed K-type spider arms (test \#2), results showed that the systems had large in-plane drift capacities due to a rigid body translation [16]-[34], 2.1\% of lateral drift ratio for the test \#1 and 5.25\% for test \#2. Larger drift capacity was associated with three main mechanisms: built-in standard gaps between the bolts and holes within the spider arm and structural support frame connections, possibility of the Inplane rigid-body rotation of the spider arms and deformations and yielding of the spider arms allowing the system to move laterally. Failure occurred when out-of-plane movement induced by combined local bending and diagonal tensile stresses around spider arm bolted connections, lead to initiation of cracking in one of the glass panels (figure 12).

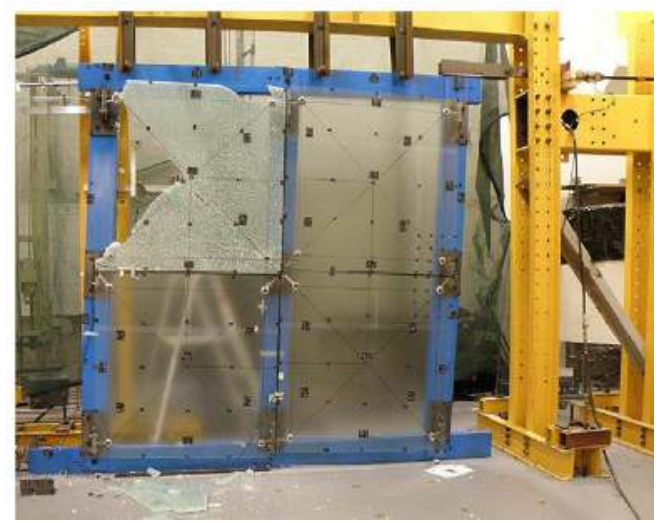

Fig. 12. The PFGFS after failure of a glass panel (Test \#2)) [30].

A computer algorithm to predict the strength and facilitate the optimization of a variety of glass bolted connections was carried out [35]. Several parameters affecting the behaviour of the system (shape of bolt, hole, closeness of fit, etc.) were studied, along with the results of a Finite Element (FE) analysis.

The effects of seismic loading in point fixed glass panels firstly using a simplified method to determine the seismic forces transmitted to façade panels, based upon the elastic response of the system, was studied [36]. FE model was developed and seismic load was applied with a dynamic time history analysis. Laminated glass panels and a set of different parameters were considered, 
variations on thickness of glass panels and interlayer type (PVB and SentryGlass). Results showed that the simplified methods to determine seismic forces transmitted to façade panels were able to capture resonance effects induced by building's natural frequency that were obtained by numerical simulations using the time history analyses. It was concluded that special attention should be take into account to avoid loads that will induce natural frequencies on glass panels close to building's natural period, and that given the case, improvement of seismic behaviour with the use of special devices to allow an increase of damping ratio is necessary.

Furthermore, FE models were undertaken to model PFGFS including structural support frame to which racking load was applied [37], non-linearity was modelled both for the behaviour of the built-in gaps and for the out-of-plane differential movement of glass panels and the deformations of the sealant, spiders on the other side, were modelled as linear elastic elements. The FE models were used to predict the raking performance of the PFGFS with different configurations: multiple grid, sealant types (weather sealant, structural and special purpose sealants), sealant thickness and glass geometry, glass thickness $(12,10$ and $15 \mathrm{~mm})$. Finding out that the racking performance of the PFGF systems increased when the stiffness of the silicone sealant was reduced while its thickness increases, when panel height to width ratio was increased as well as glass thickness.

Code Provisions for In-Plane Drift Demands

Glazing systems can be designed using a variety of glass configurations for frame, glass types (material, heat-treatment) and method of glass-to-frame attachment, but due to all those different configurations, in-plane load, namely seismic load and displacement (drift) response, will be different, therefore an increasing need to include this structures not only as general non-structural elements, as the current design considerations are in codes, but to define expected behaviour under different conditions. Nowadays, further experimental tests and finite element analysis are required in order to investigate the performance of non-typical configurations of glazing systems under seismic loads, therefore most of the designers follow general rules for lateral displacements tolerances, due to the lack of published studies specially for PFGFS.

Design codes specify design loads for out-of-plane and in-plane serviceability and ultimate limit state criteria for buildings, common practice of design codes specify limitations to inter-story drift in reference to the structural frame to avoid damages to the non-structural components, this includes glass facades. In table 2 a report on codes that refer to glazed facades are enlisted [39].

TABLE II: Specification of Codes Regarding Design and Verification of Glazed Curtain Walls [39]

\begin{tabular}{cccc}
\hline Region & Code & Seismic capacity? & Seismic demand? \\
\hline USA & AAMA 501.6 (2001) & Yes: definition of a testing procedure & No \\
USA & FEMA 450 (2003) & No & Yes, in terms of drift \\
USA & ASCE 7-10 (2013) & No & Yes, in terms of dritt \\
Japan & JASS 14 (1996) & No & Yes, in terms of drift \\
Europe & UNI EN 13830(2015) & Yes: definition of a testing procedure & No \\
\hline
\end{tabular}

Almost all the current design code provisions include specification for Inter-story drift ratios limitation under lateral load (IDRs), in general those limits are specified according to the building's main structural seismic resistant system. In table 3 are enlisted different codified IDRs for buildings ([33]; [39]). No straight specifications exist for glass façades, current practice specifies to develop experimental set-ups for non-typical configurations, and different treatment is given to the non-structural elements on each design code. 
TABLE III: Specification of Codes For Inter-Storey Drift Ratios.

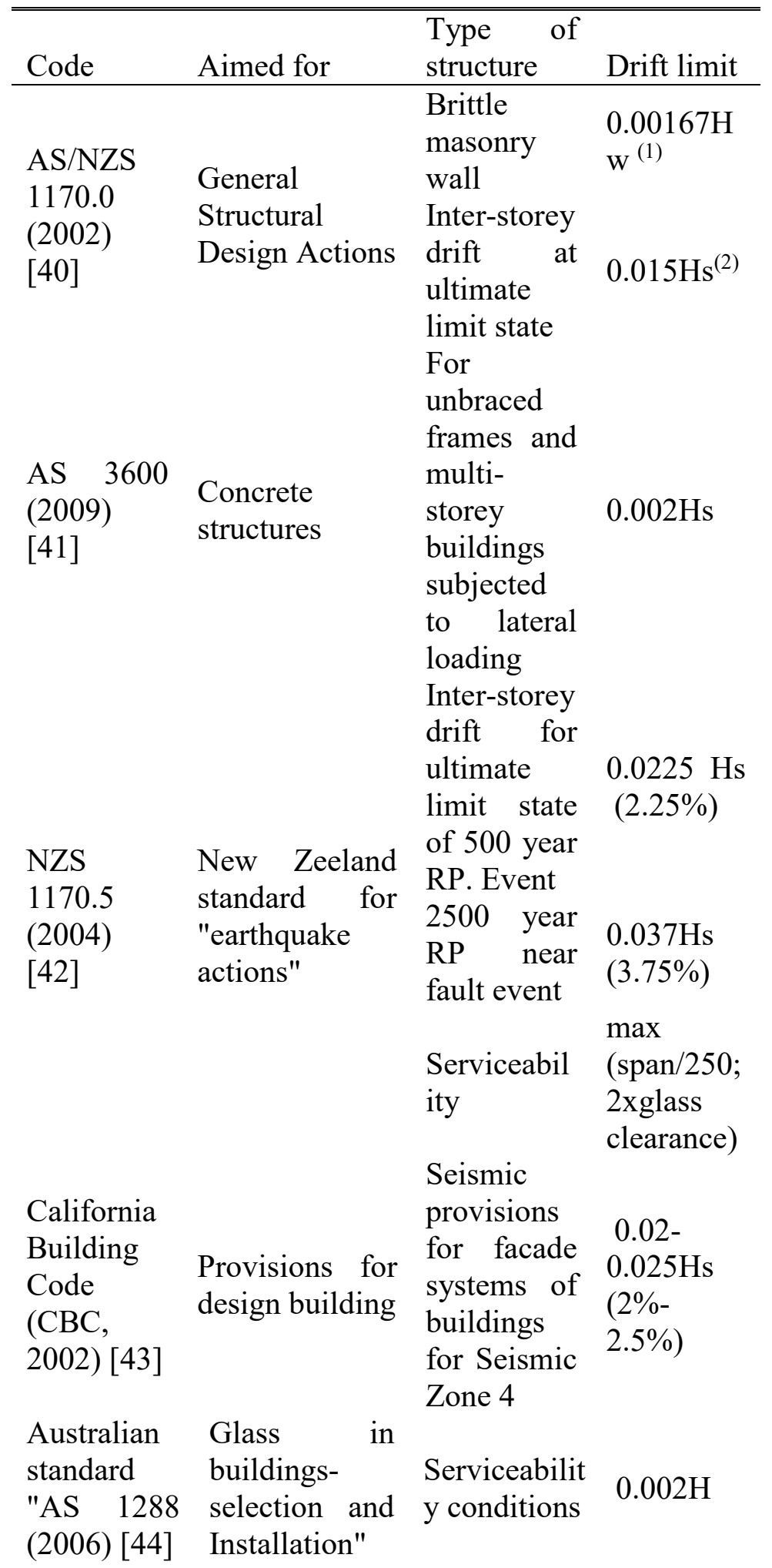




\begin{tabular}{|c|c|c|c|}
\hline $\begin{array}{l}\text { FEMA 450- } \\
1 \\
{[45]}\end{array}$ & $\begin{array}{l}\text { Structural } \\
\text { design criteria }\end{array}$ & $\begin{array}{l}\text { Structures } \\
\text { that not } \\
\text { include } \\
\text { masonry } \\
\text { seismic } \\
\text { resistant } \\
\text { systems } \\
\text { (Seismic } \\
\text { group I) }\end{array}$ & $0.02 \mathrm{Hs}$ \\
\hline $\begin{array}{l}\text { EC-8 (BS } \\
\text { EN 1997- } \\
1.2004) \\
{[46]}\end{array}$ & $\begin{array}{l}\text { Buildings } \\
\text { with non- } \\
\text { structural } \\
\text { components } \\
\text { with no } \\
\text { ductility }\end{array}$ & $\begin{array}{l}\text { Damage } \\
\text { limitation }\end{array}$ & $0.0075 \mathrm{Hs}$ \\
\hline $\begin{array}{l}\text { ASCE/SEI } \\
7-10(2010) \\
{[47]}\end{array}$ & $\begin{array}{l}\text { For } \\
\text { experimental } \\
\text { layout carried } \\
\text { out with } \\
\text { AAMA } \\
\text { specifications } \\
\text { Guideline for } \\
\text { Seismic Risk } \\
\text { Reduction of } \\
\text { Operational } \\
\text { and } \\
\text { Functional } \\
\text { Components } \\
\text { (OFCs) of } \\
\text { Buildings }\end{array}$ & $\begin{array}{l}\text { Ultimate } \\
\text { limit state } \\
\text { for steel } \\
\text { framed } \\
\text { buildings }\end{array}$ & $\begin{array}{l}\Delta \text { fallout> } \\
1.25 \mathrm{IDp}^{(3)} \\
\text { or } 13 \mathrm{~mm}\end{array}$ \\
\hline
\end{tabular}

(1) Hw masonry wall height.

(2) Hs story height.

(3) I: importance factor; Dp: relative seismic displacement.

\section{Conclusion}

An overview of current research regarding Structural Glass Façades has been presented, focusing on Point Fixed Glass Façades Systems (PFGFS). It is important to recognize that the in-plane racking performance of typical PFGFS it's an ongoing research topic, aiming to develop clear guidelines for testing protocols and analytical techniques. Simplified approaches for designer 
engineers are required to be developed as well as clear code specifications as it has been developed for Curtain Wall Façades Systems.

Acknowledgment

Financial support from the Portuguese Foundation for Sciences and Technology (Fundação da Ciência e Tecnologia) under contract grant POCI-01-0145-FEDER-032539 (GF-Seismic | Structural Glass Facades Subjected to Seismic Load) is gratefully acknowledged.

\section{References}

[1] R. Nijsse, "The Future of all glass structures", In Proceedings of IASS Annual Symposia, pp. 1-7, vol. 2015.

[2] A. Aksamija, "Sustainable Façades: Design Methods for High-Performance Building Envelopes", John Wiley and Sons, Hoboken, New Jersey, 2013.

[3] G. Dodd, "Essential elements of bolted structural glass systems". Proceedings of the International Conference in Building Envelope Systems and Technology, Centre for Window \& Cladding Technology (ICBEST'97), eds. S. Ledbetter, R. Harris, p. 92, vol. 76, 1997.

[4] P. Ryan, O. Mike and R. G. Ogden. "Steel supported glazing systems". Steel Construction Institute, Ascot, UK, 1997.

[5] A.S. Whittaker and T.T. Soong, "An overview of non-structural components research at three US Earthquake Engineering Center". Proceedings of ATC-29-2 Seminar on Seismic design, Performance and Retrofit of Non-Structural components in Critical Facilities, p. 271-280, Berkeley, CA, 2003.

[6] S. Taghavi and E. Miranda. "Response assessment of nonstructural building elements," Pacific Earthquake Engineering Research Center, 2003

[7] P. C. Jennings, "Enduring lessons and opportunities lost from the San Fernando earthquake of February 9, 1971," Earthquake spectra, vol. 13, no. 1, pp. 25-44, 1997.

[8] D. Evans, E. Kennett, W. T. Holmes and F. J. L. Ramirez, "Glass damage in the September 19, 1985 Mexico City earthquake”. Rep. Prepared for NSF, CES, 861093, 1988.

[9] S. Roeslin, Q. T. M. Ma and H. Juárez, "Damage Assessment on Buildings following the 19th September 2017 Puebla, Mexico Earthquake," Frontiers in Built Environment, vol. 4, p. 72, 2018.

[10] A. Baird, A. Palermo and S. Pampanin, "Facade damage assessment of multi-storey buildings in the 2011 Christchurch earthquake," Bulletin of the New Zealand Society for earthquake engineering, vol. 44, no 4, p. 368-376, 2011.

[11] D. Perrone, P. M. Calvi, R. Nascimbene, E. C. Fischer and G. Magliulo, "Seismic performance of non-structural elements during the 2016 Central Italy earthquake", Bulletin of Earthquake Engineering, 2018, p. 1-23, 2018.

[12] H. Sucuoğlu and C. G. Vallabhan, "Behaviour of window glass panels during earthquakes". Engineering structures, vol. 19, no 8, p. 685-694, 1997.

[13] M. Hosseini, "Behavior of nonstructural elements in the 2003 Bam, Iran, earthquake," Earthquake Spectra, vol. 21, no S1, p. 439-453, 2005.

[14] A. Baird, and H. Ferner, "Damage to non-structural elements in the 2016 Kaikōura earthquake”. Bull. New Zeal. Soc. Earthq. Eng., no 2, p. 187-193, 2017.

[15] G. James is glass Handbook, G. James Australia Pty Ltd., Australia, 2000.

[16] S. Sivanerupan, J. L. Wilson, E. F. Gad and N. T. K. Lam, "In-plane drift capacity of contemporary point fixed glass façade systems," Journal of Architectural Engineering, 2013, vol. 20, no 1, 2013. 
[17] C. Silveira, "Controlo da Qualidade de Fachadas em Vidrio Fachadas-Cortina e Fachadas em Vidrio Exterior Agrafado," Master dissertation, Dept. Civil. Eng., IST Técnico Lisboa, Lisboa, Portugal, 2018.

[18] Fitechnic website: https://www.glasscon.com/projects/ceramic-cladding-spider-glasscurtain-wall-tension-rod.

[19] GLASSCON website: https://www.glasscon.com/projects/ceramic-cladding-spider-glasscurtain-wall-tension-rod.

[20] I. Sakamoto, "Seismic performance of nonstructural and secondary structural elements," University of California, Earthquake Engineering Research Center, Rep. No. EERC-78/10, 1978.

[21] R. A. Behr, A. Belarbi and A. T. Brown, "Seismic performance of architectural glass in a storefront wall system”. Earthquake Spectra, vol. 11, no 3, p. 367-391, 1995.

[22] K. Y. S. Lim and A. B. King, "The behaviour of external glazing systems under seismic in-plane racking”. BRANZ, 1991.

[23] R. A. Behr, "Seismic performance of architectural glass in mid-rise curtain wall," Journal of Architectural Engineering, vol. 4, no 3, p. 94-98, 1998.

[24] Recommended static test method for evaluating curtain wall and storefront systems subjected to seismic and wind induced inter-story drifts, Publication No. AAMA 501.4-01$2001 \mathrm{a}$.

[25] Recommended dynamic test method for determining the seismic drift causing glass fallout from a wall system, Publication No. AAMA 501.6-01-2001b.

[26] R. A. Behr, "Design of architectural glazing to resist earthquakes," Journal of architectural engineering, 2006, vol. 12, no 3, p. 122-128.

[27] A. M. Memari, R. A. Behr, R. A. And P. A. Kremer, "Seismic behaviour of curtain walls containing insulating glass units," Journal of architectural engineering, vol. 9, no 2, p. 70-85, 2003.

[28] A. M. Memari, R. A. Behr, R. A. And P. A. Kremer, "Dynamic racking crescendo tests on architectural glass fitted with anchored pet film," Journal of Architectural Engineering, vol. 10, no 1, p. 5-14, 2004.

[29] C. Bedon, X. Zhang, F. Santos, D. Honfi, M. Kozłowski, M. Arrigoni and D. Lange, "Performance of structural glass facades under extreme loads-Design methods, existing research, current issues and trends," Construction and Building Materials, vol. 163, p. 921937, 2018.

[30] I. Maniatis, "Numerical and experimental investigations on the stress distribution of bolted glass connections under in-plane loads," Ph.D. dissertation, Technische Universität München, 2006.

[31] P. Desai, A. Golmohammadi, R. Garlipp and B. Gowda, "New point supported glass seismic system," Proceedings of the First International Conference on Advances in Experimental Structural Engineering (AESE 2005), Nagoya, Japan, 2005.

[32] B. Gowda and N. Heydari, "High displacement glass seismic systems", Practice Periodical on Structural Design and Construction, ASCE, Vol. 15, No. 2, pp. 170-176, 2009.

[33] S. Sivanerupan, "In-plane seismic performance of glass facade systems," Ph.D. dissertation, University of Technology, Victoria, Australia, 2011.

[34] S. Sivanerupan, J. L. Wilson, E. F. Gad, E. F., and N. T. K. Lam, "Drift performance of point fixed glass façade systems," Advances in Structural Engineering, vol. 17, no 10, p. 1481-1495, 2014. 
[35] M. Overend, "Optimizing connections in structural glass," In Proceedings of 2nd International conference on Glass in Buildings, 2005.

[36] L. Martins, R. Delgado, R. Camposinhos, and T. Silva, "Seismic Behaviour of Point Supported Glass Panels," Challenging Glass 3: Conference on Architectural and Structural Applications of Glass, Faculty of Civil Engineering and Geosciences, Delft University of Technology, p. 281, June, 2012.

[37] S. Sivanerupan, J. L. Wilson, E. F. Gad, E. F., and N. T. K. Lam, "Analytical study of point fixed glass façade systems under monotonic in-plane loading," Advances in Structural Engineering, vol. 19, no 4, p. 611-626, 2016.

[38] N. Caterino, M. Del Zoppo, G. Maddaloni, A. Bonati, G. Cavanna and A. Occhiuzzi, "Seismic assessment and finite element modelling of glazed curtain walls" Structural Engineering and Mechanics, vol. 61, no 1, p. 77-90, 2017.

[39] B. Huang, S. Chen, W. Lu and K. M. Mosalam, "Seismic demand and experimental evaluation of the nonstructural building curtain wall: A review," Soil Dynamics and Earthquake Engineering, vol. 100, p. 16-33, 2017.

[40] Structural design actions, Part 0: General principles, Australian/New Zealand Standard AS/NZS1170.0-2002.

[41] Concrete structures, Australian Standard - AS3600-2009

[42] Structural design actions, Part 5: Earthquake actions. New Zealand Standard NZS 1170.52004.

[43] California building code: California code of regulations, Title 24, Part 2 (Volume 1), CBC2002

[44] Glass in buildings -Selection and installation. Australian Standard AS1288-2006.

[45] NEHRP Recommended Provisions for Seismic Regulations for new Buildings and Other structures, Part 1: provisions, FEMA 450-2003.

[46] Eurocode 8: design of structures for earthquake resistance- Part 1: general rules, seismic actions and rules for buildings, BS EN 1998-1-2004.

[47] Minimum design loads for buildings and other structure, ASCE7-10-2010

[48] Guideline for seismic risk reduction of operational and functional components (OFCs) of buildings, CSA-S832-2006.

[49] R. A. Behr, Architectural glass to resist seismic and extreme climatic events; Cambridge, U. K.: Woodhead Publishing Limited, 2009, ch. 2, pp. 36-51.

[50] P. C. Jennings, "Enduring Lessons and Opportunities Lost from the San Fernando Earthquake of February 9, 1971," Earthquake Spectra vol. 13, no 1, pp. 25-44, 1997.

[51] EEFIT, "The Hyogo-Ken Nanbu (Kobe) Earthquake of 17 January 1995," Earthquake Engineering Field Investigation Team pp. 4.1-4.42, March, 1997.

[52] D. Perrone, P. M. Calvi, R. Nascimbene, E. C. Fisher and G. Magliulo "Seismic Performance of non-structural elements during the 2016 Central Italy earthquake," Bulletin of Earthquake Engineering, pp. 1-23, 2018. 